Received: 1 May 2018

Accepted: 11 January 2019

Published online: 18 March 2019

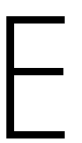

C N IF
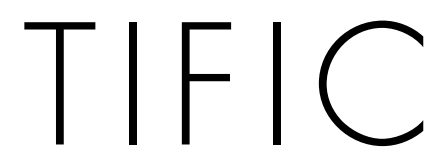

REP

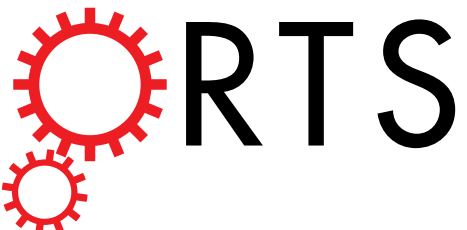

\title{
OPEN
}

\section{Response of the daily transpiration of a larch plantation to variation in potential evaporation, leaf area index and soil moisture}

\author{
Yunni Wang ${ }^{1,2}$, Gongxiang Cao ${ }^{1,2}$, Yanhui Wang ${ }^{2}$, Ashley A. Webb ${ }^{3,4}$, Pengtao $\mathrm{Yu}^{2} \&$ \\ Xiaojiang Wang ${ }^{1}$
}

Tree transpiration $(\mathrm{T})$ is a major water budget component and varies widely due to the integrated effects of many environmental and vegetation factors. This study aimed to separate, quantify, and then integrate the effects of the main individual factors, to improve water use estimation and manage the hydrological impacts of forests. A field study was conducted at 3 plots of larch (Larix principis-rupprechtii) plantation in the semi-humid area of the Liupan Mountains, northwest China. The main influencing factors were the atmospheric evaporative demand expressed by potential evapotranspiration (PET), the soil water availability expressed by volumetric soil moisture (VSM) within the $0-100 \mathrm{~cm}$ layer, and the canopy transpiration capacity expressed by forest canopy leaf area index (LAI). The daily stand T was estimated through the up-scaling of sap-flow data from sampled trees. It displayed a high degree of scattering in response to PET, VSM and LAI, with an average of $0.76 \mathrm{~mm} \cdot$ day $^{-1}$ and range of $0.01-1.71 \mathrm{~mm} \cdot$ day $^{-1}$ in the growing season of 2014 . Using upper boundary lines of measured data, the response tendency of $T$ to each factor and corresponding function type were determined. The T increases firstly rapidly with rising PET, VSM and LAI, then gradually and tends to be stable when the threshold of PET $\left(3.80 \mathrm{~mm} \cdot\right.$ day $\left.^{-1}\right)$, VSM $\left(0.28 \mathrm{~m}^{3} \cdot \mathrm{m}^{-3}\right)$ and LAI (3.7) is reached. The T response follows a quadratic equation for PET and saturated exponential function for VSM and LAI. These individual factor functions were coupled to form a general daily $T$ model which was then fitted using measured data as: $T=\left(0.793 P E T-0.078 P E T^{2}\right) \cdot(1-\exp (-0.272 L A l)) \cdot(1-\exp (-9.965 V S M))$. It can well explain the daily T variation of all 3 plots $\left(R^{2}=0.86-0.91\right)$, and thus can be used to predict the response of daily $\mathrm{T}$ of larch stands to changes in both environmental and canopy conditions.

In the dryland regions of China, vegetation restoration has been implemented for several decades through large-scale afforestation programs such as the "Three-North Forest Shelterbelt" Program since 1978, the "Natural Forest Protection" Program since 1998, and the "Grain for Green" Program since 1999, with the main purpose of protecting soil against serious erosion and sandstorms ${ }^{1-4}$. Further afforestation activities have been planned as a measure to strengthen the carbon sequestration function of forests (http://www.gov.cn/ldhd/2009-09/23/ content_1423825.htm). However, as a result of ignoring the vegetation carrying capacity of limited water resources, the large-scale afforestation has induced several unexpected problems, such as soil desiccation ${ }^{4-6}$, "little-old-trees"7 and water yield reduction ${ }^{8-10}$. This threatens the forest stability, forest ecosystem services, and the regional water supply security and sustainable development. Therefore, the accurate estimation of water consumption of forests under changing environmental conditions is urgently required.

Tree transpiration $(\mathrm{T})$ is an important physiological and hydrological process ${ }^{11,12}$ and the main cause of water loss from forest ecosystems in dryland regions ${ }^{9,13}$, thus directly affecting the forest stability and water yield from forestland and forested watersheds. The T varies widely due to the effects of numerous factors ${ }^{13}$, which can be

${ }^{1}$ Inner Mongolia Academy of Forestry Sciences, Hohhot, 010010, China. ${ }^{2}$ Institute of Forest Ecology, Environment and Protection, Chinese Academy of Forestry, Beijing, 100091, China. ${ }^{3}$ NSW Department of Primary Industries, Tamworth Agricultural Institute, Calala, NSW, 2340, Australia. ${ }^{4}$ Present address: WaterNSW, PO Box 1251, Tamworth, NSW, 2340, Australia. Yunni Wang and Gongxiang Cao contributed equally. Correspondence and requests for materials should be addressed toY.W. (email: wangyh@caf.ac.cn) 

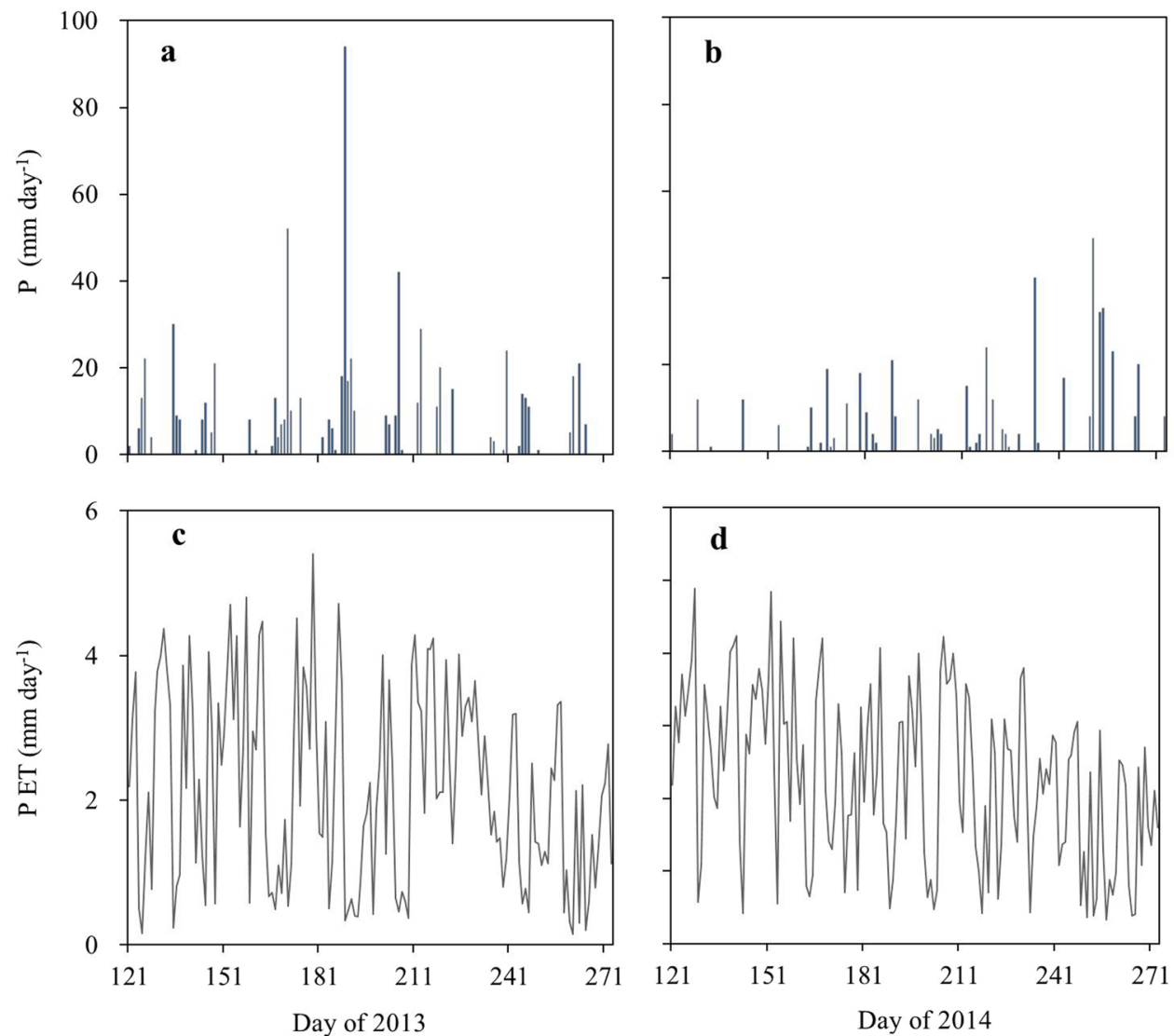

Figure 1. Variations of daily precipitation ( $\mathbf{a}$ and $\mathbf{b}$ ) and PET (c and d) during the growing seasons of 2013 and 2014.

simplified and divided into three aspects: the potential evapotranspiration of the atmosphere $(\mathrm{PET})^{14,15}$, the water supply ability from root zone soil ${ }^{13,15-17}$ and the water conveying capacity of vegetation ${ }^{18-20}$.

Across a broad range of species and ecosystems, it was found that the $\mathrm{T}$ initially increases quickly and almost linearly with rising soil moisture to a threshold ${ }^{15,16,21-25}$, then gradually to approach its potential maximum. However, the threshold value has varied among different studies. The response of $\mathrm{T}$ to soil moisture can be described with logistic or quadratic relations, or segmented linear relations. Most such studies were designed for understanding the T response only to soil drying and were conducted in pots or chambers under controlled weather conditions. In the limited field studies, the data during cloudy, overcast, rainy days or those with extreme vapor pressure deficit (VPD) were often excluded, to derive a moderate relation between $\mathrm{T}$ and soil moisture ${ }^{16,26-28}$, so such results cannot fully reflect the $\mathrm{T}$ behavior in the field. In most cases, the forest $\mathrm{T}$ is controlled not only by soil moisture, except during the periods with high enough soil water deficit ${ }^{16,23,29,30}$, but also strongly by the wide variation of atmospheric evaporative demand and available energy ${ }^{13,31,32}$, which can be simply represented by the integrated index of $\mathrm{PET}^{29,33}$. In addition, the dynamic leaf amount in canopy is the most important active factor influencing the water conveying ability of forests, and inevitably leads to the T variation. The T increases nonlinearly with rising LAI, as confirmed in a controlled study ${ }^{34}$.

Most studies on forest $\mathrm{T}$ variation have considered only one or two of the influencing factors of soil moisture, meteorological factors and LAI. For example, Li et al. ${ }^{33}$ studied the T of a larch plantation in the middle of the growing season to analyze the effect of PET and relative extractable soil water (REW), but without consideration of LAI. The lack of field studies, which consider the coupled effects of all the main influencing factors, limits the understanding and accurate prediction of forest $\mathrm{T}$ under changing environmental conditions, and the integrated forest-water management in a multifunctional way.

Thus, to describe the variation of daily T of forest stands under changing PET, VSM and LAI, and to evaluate the effects of these factors, as well as to predict the T variation with a comprehensive model, this study was carried out in 3 plots of Prince Rupprecht's larch (Larix principis-rupprechtii) plantation at the Liupan Mountains area located in the transitional zone between the semi-humid and semi-arid regions of northwest China.

\section{Results}

Variations of LAI, weather and soil moisture. The daily precipitation $(\mathrm{P})$ and PET in the study period from the $1^{\text {st }}$ May to the $30^{\text {th }}$ September in 2013 and 2014 are shown in Fig. 1. The precipitation in the growing season of 2013 was high, with a total of $718.0 \mathrm{~mm}$. The precipitation in the growing season of 2014 was relative low, with a total of $484.0 \mathrm{~mm}$, and unevenly distributed with just $29 \mathrm{~mm}$ in May, $80 \mathrm{~mm}$ in June, $78 \mathrm{~mm}$ in July, $116 \mathrm{~mm}$ 

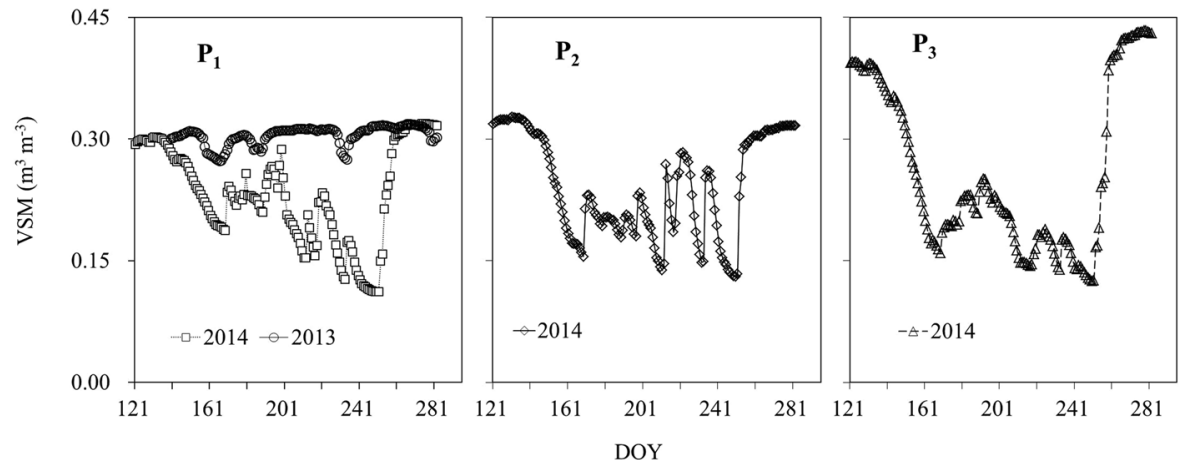

Figure 2. Variation of daily volumetric soil moisture of the $0-100 \mathrm{~cm}$ layer in the growing season of 2013 and 2014.
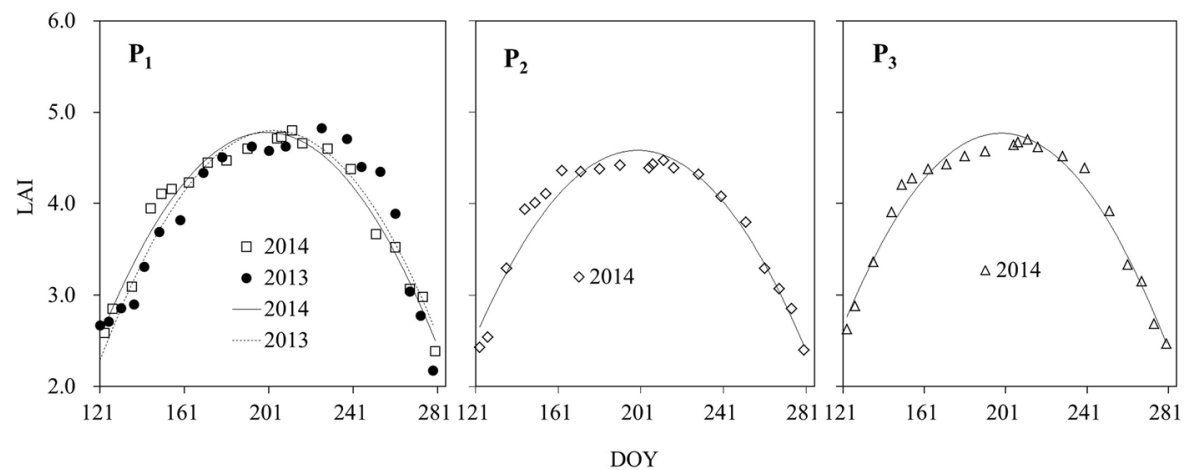

Figure 3. Variation pattern of forest canopy LAI in the growing seasons of 2013 and 2014.

in August and $181 \mathrm{~mm}$ in September. The total PET in the study period was $332.18 \mathrm{~mm}$ in 2013 and $348.1 \mathrm{~mm}$ in 2014, respectively, with a daily mean PET of $2.17 \mathrm{~mm} \cdot$ day $^{-1}$ in 2013 and $1.80 \mathrm{~mm} \cdot$ day $^{-1}$ in 2014 . The daily PET fluctuated strongly, e.g., within the range of $0.13-4.89 \mathrm{~mm} \cdot \mathrm{day}^{-1}$ in 2014.

Figure 2 shows the seasonal variation pattern of VSM in the $0-100 \mathrm{~cm}$ soil layer during the study period. There was a common tendency of three-stage variation of "rapid consumption - continued volatility - recovery" for all plots in 2014. However, a significant difference in soil moisture quantity existed among plots, e. g., the highest values of VSM at the beginning and end of the study period in 2014 were significantly larger in $\mathrm{P}_{3}$ than in $\mathrm{P}_{2}$ and $\mathrm{P}_{1}$, because of the relatively higher soil capillary porosity in $\mathrm{P}_{3}$. The VSM fluctuated strongly from DOY 165 to 248 as the result of counteracting rainfall input and evapotranspiration output. In the period after DOY 248, the VSM was lifted rapidly and then kept at a high level, due to sufficient recharge from heavier rainfall and reduced evapotranspiration. This suggested that the VSM differences among plots and with time were influenced by weather, vegetation growth, evapotranspiration and the physical features of soil. It should be noted that the VSM in P1 in 2013 was obviously higher and more stable than that in 2014 due to the high and evenly distributed precipitation in 2013.

Canopy LAI is an important vegetation factor influencing forest transpiration. The seasonal variation pattern of LAI of all plots presented the same trend of "increase - decrease" (Fig. 3), but there was some difference in the peak values and variation processes of LAI among plots due to their difference in site environment. For example, the peak LAI was 4.80, 4.47, 4.70 and the minimum LAI was $2.39,2.40$, and 2.47 in $\mathrm{P}_{1}, \mathrm{P}_{2}$ and $\mathrm{P}_{3}$ during the growing season of 2014.

Variation of transpiration. The seasonal variation trend of daily $\mathrm{T}$ was similar among the 3 plots in the growing season of 2014 (Fig. 4), but the difference in their quantities was significant (paired t-test, $\mathrm{P}<0.01$ ). The daily T showed firstly a drastic increase prior to the DOY of 150 , then a relatively stable period during the DOY of 151-235, and thereafter a decrease until the end of the growing season. The total $\mathrm{T}$ for the study period (DOY 121-273) was $114.28 \mathrm{~mm}$ in $\mathrm{P}_{3}, 101.21 \mathrm{~mm}$ in $\mathrm{P}_{1}$, and $96.58 \mathrm{~mm}$ in $\mathrm{P}_{2}$. The peak daily $\mathrm{T}$ during the study period for $\mathrm{P}_{1}, \mathrm{P}_{2}$ and $\mathrm{P}_{3}$ was 1.40 (DOY 147), 1.35 (DOY 149) and $1.71 \mathrm{~mm} \cdot$ day $^{-1}$ (DOY 155), respectively, and the corresponding daily averages were $0.75,0.69$ and $0.86 \mathrm{~mm} \cdot$ day $^{-1}$. The T difference among plots was likely caused by the comprehensive influence of different soil moisture and canopy LAI.

Response of T to PET. Figure 5a shows the response of daily $\mathrm{T}$ to the variation of daily PET, with $\mathrm{P}_{1}$ as an example. The fluctuation range of $\mathrm{T}$ increases with rising PET. When using linear regression with an intercept forced to be zero, the $\mathrm{T}$ is highly related with $\mathrm{PET}\left(\mathrm{R}^{2}=0.70\right.$; slope $\left.=0.321\right)$, indicating PET can explain $70 \%$ of the $\mathrm{T}$ variation. However, only the upper boundary line ${ }^{35}$ can present the real T-PET relation, by ignoring 


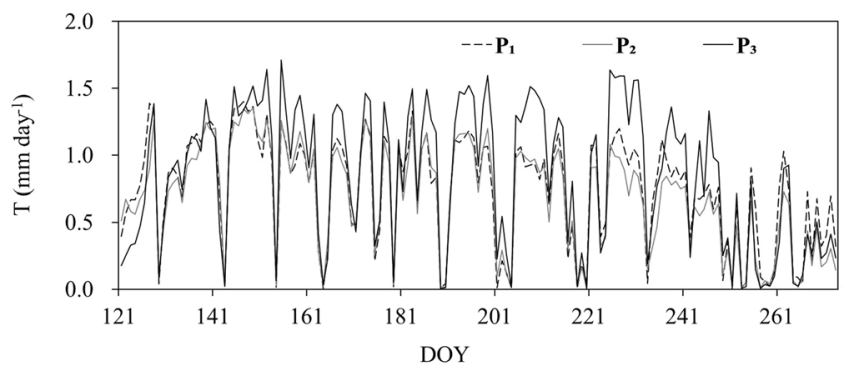

Figure 4. Seasonal variation pattern of daily transpiration of larch plantation in three plots in 2014.
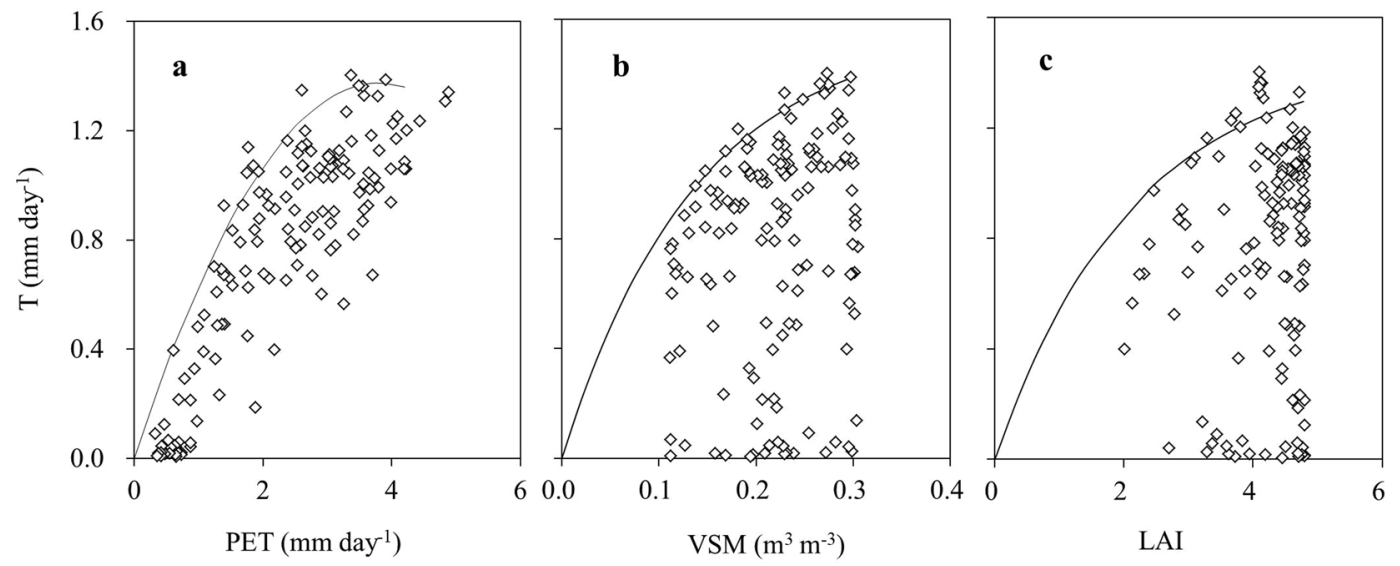

Figure 5. Response of daily T in $\mathrm{P}_{1}$ to the variation of PET, VSM of 0-100 cm soil layer and canopy LAI (solid line as upper boundary line).

the interferences of soil moisture (VSM) and canopy transpiration capacity (LAI). Based on the selected upper boundary data of $\mathrm{T}$ which are at least one standard deviation larger than the mean $\mathrm{T}$ within each PET interval $\left(0-1,1-2, \ldots, 4-5 \mathrm{~mm} \cdot\right.$ day $\left.^{-1}\right)$, a regression analysis yielded a highly significant quadratic relation as below, which can explain a high proportion of the T variance $\left(n=10, R^{2}=0.965\right)$ :

$$
T=-0.095 \times P E T^{2}+0.723 \times P E T
$$

According to the upper boundary line, the T firstly increases quickly at an almost linear rate with rising PET until $2.65 \mathrm{~mm} \cdot \mathrm{day}^{-1}$, thereafter the increasing rate decreases gradually within the PET range of $2.65-3.80 \mathrm{~mm} \cdot-$ day $^{-1}$, and finally the $\mathrm{T}$ begins to approach a constant maximum with further PET increase. This indicates that the PET acts as a primary driver of T only when the PET is below its threshold of $3.80 \mathrm{~mm} \cdot \mathrm{day}^{-1}$.

Response of T to VSM. The daily T and VSM in $\mathrm{P}_{1}$ are plotted in Fig. $5 \mathrm{~b}$ which shows that the daily $\mathrm{T}$ was highly scattered for any given soil moisture, due to strong influence from other factors. However, the upper boundary line (solid line in Fig. 5b) indicates a clear and non-linear increase of T with rising VSM. This can be well described by the saturated exponential equation (Eq. (2), $n=13, \mathrm{R}^{2}=0.987$ ). Within the VSM range of 0.08 $0.22 \mathrm{~m}^{3} \cdot \mathrm{m}^{-3}$, the boundary line increases near linearly with rising VSM at the rate of $0.12 \mathrm{~mm} \cdot \mathrm{day}^{-1}$ per 0.02 of VSM; whereas in the VSM range of $0.22-0.28 \mathrm{~m}^{3} \cdot \mathrm{m}^{-3}$, T increases slowly within a small range of $1.33-1.37 \mathrm{~mm} \cdot-$ $\mathrm{day}^{-1}$, and thereafter the boundary line remains relatively unchanged. This indicates that there is a VSM threshold of $0.28 \mathrm{~m}^{3} \cdot \mathrm{m}^{-3}$, below which the T will be limited by the soil water shortage.

$$
T=1.504 *\left(1-e^{-8.116 \times V S M}\right)
$$

Response of T to LAI. The daily T and LAI data in $\mathrm{P}_{1}$ are plotted in Fig. $5 \mathrm{c}$ which shows that the T displayed a high degree of scatter for any given LAI, due to the strong influence of other factors. To show the influence of varying LAI on T more clearly, the upper boundary line was used to analyze the T-LAI relation, and a significant saturated exponential equation was fitted (Eq. (3), $\mathrm{n}=13, \mathrm{R}^{2}=0.979$ ):

$$
T=1.453 *\left(1-e^{-0.466 \times L A I}\right)
$$

When LAI varies within the range of 2.0-3.7, the boundary line increases nearly linearly with rising LAI; thereafter the $\mathrm{T}$ increases gradually and finally tends to its potential maximum. This indicates that there is a LAI 

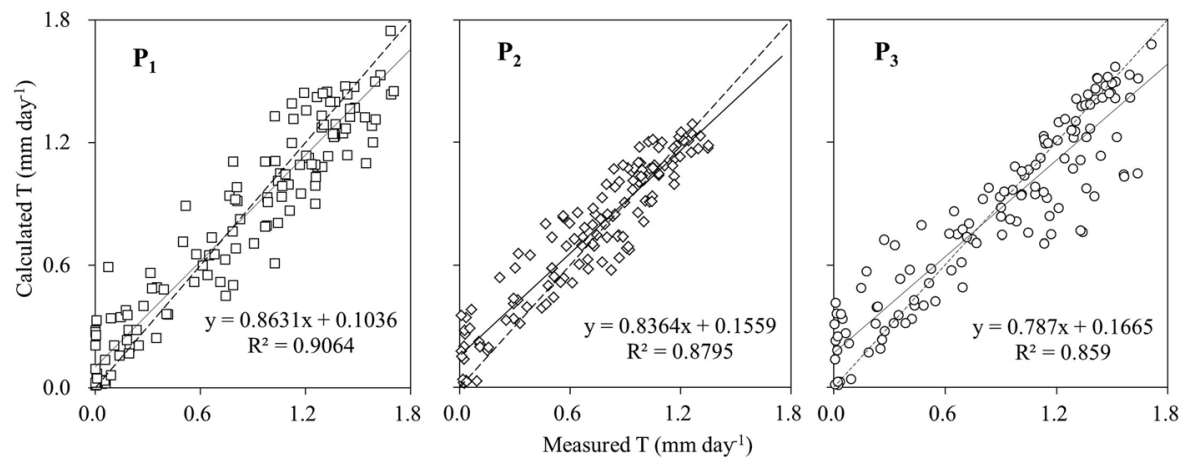

Figure 6. Comparison between model calculated and measured daily $\mathrm{T}$ in $\mathrm{P}_{1}$ (2013), $\mathrm{P}_{2}$ and $\mathrm{P}_{3}$ (2014). Dotted line is the 1:1 relation, solid line is the relation between calculated and measured values.

threshold of 3.70, above which LAI is no longer the dominant driver for T variation, but other factors are of paramount importance, such as VSM and PET.

A model estimating the daily T. In this study it was assumed that all the factors influencing forest $\mathrm{T}$ can be attributed to three aspects: the evapotranspiration pull from air (PET), the water supply ability from root zone soil (0-100 cm VSM), and the water conveyance capacity of trees (canopy LAI). To construct an integrated model which can describe the T response to PET, VSM and LAI, we coupled Eqs (1), (2) and (3) to form a general model (see Eq. (10) in Materials and methods). However, the values of all model parameters were newly fitted using field data in $\mathrm{P}_{1}$ during the entire observation period in 2014, based on the parameter values in the relations of $\mathrm{T}$ to single factors as the initial value of the fitting process. This newly fitted general T model is expressed as Eq. (4):

$$
T=\left(0.793 P E T-0.078 P E T^{2}\right) \times\left(1-e^{-0.272 L A I}\right) \times\left(1-e^{-9.965 V S M}\right) \mathrm{R}^{2}=0.91
$$

The sum of daily T calculated using Eq. (4) was $108.95 \mathrm{~mm}$ in $\mathrm{P}_{1}$ from DOY $140-273$ of 2013 , only $1.20 \mathrm{~mm}$ lower than the measured $\mathrm{T}(110.15 \mathrm{~mm})$ during the study period. The ratio between the calculated and measured value is $93.46 \%$ in May, $100.34 \%$ in June, $108.99 \%$ in July, $93.52 \%$ in August, and $99.86 \%$ in September. The daily residuals between measured and calculated $\mathrm{T}$ varies mainly between -0.51 and $0.44 \mathrm{~mm} \cdot \mathrm{day}^{-1}$ (Fig. 6), with a slight overestimation which increases with lowering daily T. The coefficient of Nash and Sutcliffe was 0.87. However, the model would overestimate the daily $\mathrm{T}$ when the measured $\mathrm{T}$ fell below $0.35 \mathrm{~mm} \cdot \mathrm{day}^{-1}$.

To further validate the effectiveness of Eq. (4), the calculated daily $\mathrm{T}$ values were compared with measured data in $\mathrm{P}_{2}$ and $\mathrm{P}_{3}$ from DOY 121-273 of 2014, and they agree well $\left(\mathrm{R}^{2}=0.88\right.$ in $\mathrm{P}_{2}, 0.86$ in $\left.\mathrm{P}_{3}\right)$ (Fig. 6). The sum of calculated $\mathrm{T}$ in $\mathrm{P}_{2}$ and $\mathrm{P}_{3}$ was 102.98 and $118.97 \mathrm{~mm}$, which is only $6.22 \%$ higher and $2.11 \%$ lower than the measured values, with a satisfactory coefficient of Nash and Sutcliffe of 0.83 and 0.82 , respectively.

From the above analysis it can be said that the model has the ability to accurately predict the daily $\mathrm{T}$ which matches the measured data well $\left(\mathrm{R}^{2}=0.86-0.91\right.$ for 3 plots, Fig. 6$)$, and covers a broad variation range of PET, VSM and LAI. So the model can well reflect and explain the influence of the main factors affecting the forest daily $\mathrm{T}$.

The impact of PET, VSM and LAI on T. From the observed weather data in 2010-2014 (data from 20102012 are not shown here), the maximum daily PET was picked out as the highest daily evaporative demand at the research site, with a value of $5.39 \mathrm{~mm} \cdot \mathrm{day}^{-1}$. In addition, we assumed the maximum VSM of $0.45 \mathrm{~m}^{3} \cdot \mathrm{m}^{-3}$ and LAI of 5.00 based on previous studies at the same site. These maximum values of PET, VSM and LAI were then used to calculate the daily potential maximum $\mathrm{T}\left(\mathrm{T}_{\max }\right)$ using Eq. (4). The sum of these calculated daily potential $\mathrm{T}$ in the whole study period is $226.44 \mathrm{~mm}$, which reflects the potential total T when PET, VSM and LAI are not limited. These values will be used as a reference to assess the impact of each factor on forest $\mathrm{T}$.

To assess the impact of individual factors on $\mathrm{T}$, the actual data of the factor to be assessed in the study period in 2014, and the maximum values of other two factors were brought into Eq. (4) to calculate the daily $\mathrm{T}$ and their totals $\left(\mathrm{T}_{t}\right)$ for $\mathrm{P}_{1}, \mathrm{P}_{2}$ and $\mathrm{P}_{3}$. Differences between the daily potential maximum $\mathrm{T}\left(\mathrm{T}_{\max }\right)$ and their totals were calculated and used for this assessment (Table 1). The results show that the $\mathrm{T}$ reduction due to the limit of actual PET amounts to $80.78 \mathrm{~mm}(35.67 \%)$ in the study period for all plots; the corresponding T reduction is $26.30(11.61 \%)$, $23.81(10.51 \%)$ and $25.01 \mathrm{~mm}(11.04 \%)$ due to the insufficient VSM, and $25.71(11.35 \%), 20.20(8.92 \%)$ and $23.71 \mathrm{~mm}(10.49 \%)$ due to the insufficient LAI in $\mathrm{P}_{1}, \mathrm{P}_{2}$ and $\mathrm{P}_{3}$, respectively. This indicates the dominant limiting factor is PET, followed by the VSM and LAI.

\section{Discussion}

The simplification of T response to changing environmental conditions. In this study, the numerous factors influencing forest $\mathrm{T}$ were simplified and divided into three aspects: the PET reflecting the atmospheric evaporative demand, the VSM reflecting the water supply ability, and the canopy LAI reflecting the stand transpiration capacity. For a given stand with fixed site condition, these three aspects must be the most important driving forces for forest $\mathrm{T}$. As a result of their joint influences, the daily $\mathrm{T}$ of the larch plantation located in a semi-humid region in this study varied in a wide range of $0.01-1.71 \mathrm{~mm} \cdot$ day $^{-1}$ during the growing season of 2014 . However, 


\begin{tabular}{|c|c|c|c|c|c|c|}
\hline $\begin{array}{l}\text { Plots } \\
\text { No. }\end{array}$ & $\begin{array}{l}\text { T calculated as VSM }=0.45 \\
\mathrm{LAI}=5.00 \text {, and actual PET }\end{array}$ & $\begin{array}{l}\text { T calculated as PET }=5.39 \\
\mathrm{LAI}=5.00 \text {, and actual VSM }\end{array}$ & $\begin{array}{l}\text { T calculated as PET }=5.39 \\
\text { VSM }=0.45, \text { and actual LAI }\end{array}$ & $\begin{array}{l}\text { T Reduction by the } \\
\text { actual PET limit }\end{array}$ & $\begin{array}{l}\text { T Reduction by the } \\
\text { actual VSM limit }\end{array}$ & $\begin{array}{l}\text { T Reduction by the } \\
\text { actual LAI limit }\end{array}$ \\
\hline $\mathrm{P}_{1}$ & \multirow{3}{*}{145.66} & 200.14 & 200.73 & \multirow{3}{*}{$80.78(35.67 \%)$} & $26.30(11.61 \%)$ & $25.71(11.35 \%)$ \\
\hline $\mathrm{P}_{2}$ & & 202.63 & 206.24 & & $23.81(10.51 \%)$ & $20.20(8.92 \%)$ \\
\hline $\mathrm{P}_{3}$ & & 201.43 & 202.73 & & $25.01(11.04 \%)$ & $23.71(10.49 \%)$ \\
\hline
\end{tabular}

Table 1. The total T reductions ( $\mathrm{mm}$ ) in the study period of 2014 by the limit of single factors (PET, VSM, LAI) for $\mathrm{P}_{1}, \mathrm{P}_{2}$ and $\mathrm{P}_{3}$ compared with the total potential maximum $\mathrm{T}$ of $226.44 \mathrm{~mm}$.

\begin{tabular}{|c|c|c|c|c|c|c|c|c|c|c|c|}
\hline Plot No. & Elevation m & \begin{tabular}{|l} 
Slope \\
position
\end{tabular} & $\begin{array}{l}\text { Stand density } \\
\text { trees.ha }^{-1}\end{array}$ & $\begin{array}{l}\text { Canopy } \\
\text { density }\end{array}$ & $\begin{array}{l}\begin{array}{l}\text { Mean tree } \\
\text { height } \mathrm{m}\end{array} \\
\end{array}$ & \begin{tabular}{|l|} 
Mean tree \\
$\mathrm{DBH} \mathrm{cm}$
\end{tabular} & \begin{tabular}{|l|} 
Canopy \\
LAI
\end{tabular} & \begin{tabular}{|l|}
$\begin{array}{l}\text { Soil bulk } \\
\text { density } \mathrm{g} \cdot \mathrm{cm}^{-3}\end{array}$ \\
\end{tabular} & \begin{tabular}{|l|l|} 
Total soil \\
porosity $\%$
\end{tabular} & $\begin{array}{l}\text { Soil capillary } \\
\text { porosity } \%\end{array}$ & $\begin{array}{l}\text { Field } \\
\text { capacity \%,v }\end{array}$ \\
\hline $\mathrm{P}_{1}$ & 2394.2 & Middle & 930 & 0.74 & 19.07 & 20.49 & $2.39-4.80$ & 1.21 & 48.91 & 32.70 & 36.65 \\
\hline $\mathrm{P}_{2}$ & 2276.6 & Lower & 933 & 0.75 & 16.00 & 18.85 & $2.40-4.47$ & 1.11 & 51.73 & 37.91 & 45.50 \\
\hline $\mathrm{P}_{3}$ & 2283.1 & Lower & 1139 & 0.80 & 14.85 & 18.48 & $2.47-4.70$ & 1.09 & 51.40 & 41.21 & 46.17 \\
\hline
\end{tabular}

Table 2. General site, vegetation and $0-100 \mathrm{~cm}$ soil layer descriptions of the larch plantation plots.

the response of T to individual factors (PET, VSM and LAI) is hard to derive and quantify when using a simple response-surface analysis of field data and the determination of corresponding thresholds of these factors is even not possible ${ }^{36}$. Therefore, the technique of upper boundary line was applied in this study.

Meteorological factors are the major drivers of T, as shown in Table 3 based on this study. Many relevant studies have involved numerous meteorological factors, including temperature, solar radiation, VPD, etc ${ }^{25,28,29,37,38}$. However, the research results have differed greatly, due to the large spatio-temporal variation of dominant meteorological factors. Using PET as an integrated indicator of the atmospheric evaporative demand, the comprehensive impact on $\mathrm{T}$ of multiple meteorological factors can be easily expressed and it is better than using any single meteorological factor ${ }^{13,32,38}$.

The $\mathrm{T}$ response to single factors and related thresholds. The effect of PET on daily $\mathrm{T}$ of a larch plantation was analyzed in this study using the upper boundary line technique and it was found to follow a quadratic equation. The daily $\mathrm{T}$ increases firstly almost linearly with rising PET until its threshold of $3.80 \mathrm{~mm} \cdot \mathrm{day}^{-1}$, thereafter the $\mathrm{T}$ does not increase appreciably but gradually towards its potential maximum. Such a tendency of T response to PET in our study is consistent with other studies ${ }^{15,33}$. The PET threshold of $3.80 \mathrm{~mm} \cdot$ day $^{-1}$ in our study is slightly lower than that $\left(4.00 \mathrm{~mm} \cdot \mathrm{day}^{-1}\right)$ reported by Li et al. ${ }^{33}$ for a 28 -year-old larch plantation at the semi-arid area of Liupan Mountains, probably due to the wetter climate in our semi-humid study site. Wu et al. ${ }^{25}$ found that the variation of daily $\mathrm{T}$ of black locust seedlings with PET follows a logistic function, and the PET threshold varies with soil texture, e.g., 3.2 and $4.0 \mathrm{~mm} \cdot$ day $^{-1}$ for a loamy clay soil and sandy loam soil, respectively under field conditions; whereas 3.6 and $3.9 \mathrm{~mm} \cdot \mathrm{day}^{-1}$ for a sandy loam soil and loamy clay soil, respectively within climate-controlled chambers. However, some studies have found that the $\mathrm{T}$ increases nearly linearly with rising PET, e.g., the reported average T/PET ratio of 0.55 for a Pinus pinaster forest when PET varied within $0-7 \mathrm{~mm} \cdot \mathrm{day}^{-1}$ in southern France ${ }^{14}$, and of 0.75 for a natural rain forest ${ }^{39}$. This is likely due to the high humidity in the study area and the small stomata inhibition of VPD.

Soil moisture determines the quantity of soil water available for transpiration, and its influence on $\mathrm{T}$ observed here is similar to the findings of Oren and Pataki ${ }^{22}$ in a deciduous forest, of Bindi et al..$^{24}$ in 4 -year-old grapevines in pots, and of Li et al. ${ }^{33}$ in a larch plantation. The daily T increases with rising soil moisture (expressed as VSM or REW) following non-linear models (like logistic function) or segmented linear models, firstly increasing very rapidly until a threshold of soil moisture is reached, and then leveling off to its maximum. However, the values of VSM threshold differ among these studies. For example, $0.15 \mathrm{~m}^{3} \cdot \mathrm{m}^{-3}$ in the study of Ungar et al. ${ }^{15}$ for an Aleppo pine (Pinus halepensis Mill.) stand in Israel, a REW of 0.40 in a sugar maple (Acer saccharum Marsh.) forest near Quebec City in Canada ${ }^{23}$, a REW of 0.40 in a shrub (Caragana korshinskii) on the Loess Plateau of China ${ }^{30}, 0.19 \mathrm{~m}^{3} \cdot \mathrm{m}^{-3}$ (equal to 0.45 in REW) in a 28 -year-old larch plantation in the semiarid area of Liupan Mountains ${ }^{33}$. In our study, the VSM threshold was determined as $0.28 \mathrm{~m}^{3} \cdot \mathrm{m}^{-3}$ (equal to 0.51 in REW) which is higher than all the threshold values mentioned above. The causes for this difference may be the difference in the T-VSM response and its influencing factors, such as tree species ${ }^{22,28}$, soil texture ${ }^{23,25}$ and meteorological condition ${ }^{25,32,33}$. According to a potted corn study ${ }^{40}$, the value of VSM threshold increased from 0.23 to $0.34 \mathrm{~m}^{3} \cdot \mathrm{m}^{-3}$ when the potential transpiration rate increased from 1.4 to $6.4 \mathrm{~mm} \cdot \mathrm{day}^{-1}$; Wu et al. ${ }^{25}$, based on a chamber seedling experiment, reported that the VSM threshold varied in the range of $0.213-0.222 \mathrm{~m}^{3} \cdot \mathrm{m}^{-3}$ for loamy clay soil and of $0.125-0.145 \mathrm{~m}^{3} \cdot \mathrm{m}^{-3}$ for sandy loam soil at different PET levels.

The forest canopy LAI, which varied greatly during the growing season, can directly affect the forest T. Several studies have reported the response of daily T to LAI. Bucci et al.$^{18}$ found that the response of stand T to LAI $(0<\mathrm{LAI}<3.0)$ was well described by a saturated exponential equation at 5 Brazilian savanna (Cerrado) sites, with a LAI threshold of about 2.5 above which the T does not obviously increase. Forrester $e$ al.$^{38}$ reported that the stand $\mathrm{T}$ increased with rising LAI in the range of 1.0-6.0 in young Eucalyptus nitens plantation at ages of 5.1 and 6.3 years in a humid area. However, a contrasting result was reported by Xiong et al. ${ }^{20}$ studying a 24 -years-old larch plantation in the semi-humid area of Liupan Mountains, possibly due to the high compensation from light and soil moisture. Compared with that observed by Bucci et al. ${ }^{18}$, our study found a higher LAI threshold of 3.8, 
but the same tendency of T response to LAI. The lower LAI threshold in the study of Bucci et al. ${ }^{18}$ can be partly caused by the limitation of soil nutrient availability. However, the increasing competition for light and soil water ${ }^{20}$ or limiting meteorological factors ${ }^{33}$ could be the dominant causes of the declining response rate of $\mathrm{T}$ with rising LAI in our study. The effect of canopy structure and physiology on T can be predominantly caused by the factors of $\mathrm{LAI}^{18}$, stomatal conductance ${ }^{39}$ and effective transpiration capacity of leaves. However, only the effect of varying LAI was considered in our study, while the other two factors were excluded. These may be the dominant causes of the over- or under-estimation of the daily $\mathrm{T}$ by our model in the current study.

The above discussion indicates that the tendency of T response to rising PET, VSM and LAI among the different study areas and vegetation types is mostly consistent. However, the threshold values of these factors vary with plant type, tree species, vegetation condition, soil condition, climate type and so on. In addition, some of the existing studies were conducted in chambers (e.g., Wu et al. ${ }^{25}$ ) or pots (e.g., Denmead \& Shaw ${ }^{40}$ ) usually under controlled weather conditions. In the limited field studies, the data from cloudy, overcast, raining days or those with extreme VPD were excluded ${ }^{16,26,27}$, the canopy variation was not considered (e.g., Li et al..$^{33}$ ), or the plots were treated with silvicultural interventions (e.g., Forrester et al. ${ }^{38}$ ). Therefore, these study results will be surely far different from the $\mathrm{T}$ behavior of trees in the field under natural conditions. Hence many further studies are required in future to look for the universal $\mathrm{T}$ response to the changing environmental and vegetation conditions.

Daily forest T model. Although many different field observation methods for getting stand $\mathrm{T}$ were used $^{37,39,41}$, the complete and accurate field data are still limited. To overcome this, mechanism-based T models should be developed and applied for more precise prediction ${ }^{13,18,28,33}$.

Many studies have tried to develop a stand T model based on field observations $s^{22,27,28,31,39,42,43}$. However, they have mostly considered just one or two of the main influencing factors (soil moisture, meteorological factors, vegetation condition, etc.), and the model structure was simple with the focus on reproducing $\mathrm{T}$ for a specific site. Such simplified models without coupling all the main influencing factors (PET, VSM, LAI), as shown in this study, cannot be widely applied under changing environmental conditions.

The $\mathrm{T}$ model developed in this study can predict the daily $\mathrm{T}$ of forests with an accuracy higher than or close to most of the models established previously in similar studies ${ }^{22,28,39,42,44}$. For example, the models including LAI, VPD within canopy, photosynthetically active radiation above canopy and soil moisture depletion, explained $75 \%$ and $81 \%$ of the T variation in the studies of Oren \& Pataki ${ }^{22}$ and Phillips \& Oren ${ }^{44}$. In the short period study during the middle of the growing season, when the LAI was relatively stable and the influence of some abiotic environmental factors was low ${ }^{33}$, the model describing the daily T response to the PET and REW for a larch plantation could explain $91 \%$ of the $\mathrm{T}$ variation.

The mechanism-based $\mathrm{T}$ model developed in this study has great potential for estimating the daily $\mathrm{T}$ of larch plantations under widely varying site conditions (slope position, slope aspect, etc.) if data on the main influencing factors (PET, VSM and LAI) are available. This model can also promote the deeper understanding of forest-water interactions and integrated forest-water management. Moreover, the model application can be enlarged through coupling this model with other models describing the variation of PET, VSM and LAI. Finally, the concept and framework of this model can be taken as a reference for developing similar models for other tree species and vegetation types in different regions.

The model established in this study can be further improved by the inclusion of other factors in the model framework, such as the mountain terrain shade, the depth distribution of tree roots ${ }^{45}$ and soil water ${ }^{13}$, plant diseases and insect pests ${ }^{12}$, the water deficit stress ${ }^{24}$, and the leaf injury from low temperatures. Furthermore, we do not have enough $\mathrm{T}$ data for larch plantations in different regions with varying forest structure, tree age, climate, soil texture and hydrological features, for fitting the model parameters and testing the broad applicability of this model. Therefore, more studies are required for improving and refining this model and its application.

\section{Conclusions}

The daily transpiration $(\mathrm{T})$ of a larch plantation at one semi-humid site of northwest China showed a big variation, within the range of $0.01-1.71 \mathrm{~mm} \cdot \mathrm{day}^{-1}$ in the growing season. To understand and predict the daily $\mathrm{T}$ easily, the numerous influencing factors were simplified into three aspects: the potential evapotranspiration (PET) representing the atmospheric evaporative demand, the volumetric soil moisture (VSM) within the main root zone representing the soil water availability, and the forest canopy leaf area index (LAI) representing the stand transpiration capacity. Based on the analysis of upper boundary lines, the daily T increases with rising PET, VSM, and LAI firstly rapidly, then gradually and tends to be stable when a threshold is reached. The function types of the daily $T$ response were also determined, i.e., a quadratic equation for PET and a saturated exponential function for VSM and LAI. A mechanism-based daily T model was developed through coupling the T response functions to the widely varying PET, VSM and LAI, and the model parameters were fitted based on the field measured data. This model can not only well predict the daily T of forests, but also explain $86-91 \%$ of the highly scattered variation in the daily $\mathrm{T}$ of the 3 larch plantation plots. Although this study was carried out just at one site with limited plantation plots and over a short time period, the concept and framework of this model might be a reference for other studies in different regions.

\section{Materials and Methods}

Study site. The study site is located in the southern part of the Liupan Mountains $\left(106^{\circ} 15^{\prime} \mathrm{E}, 35^{\circ} 29^{\prime} \mathrm{N}\right)$ in northwest China, which forms the important headwater area of several tributaries of the Yellow River. The study was carried out at the small watershed of Xiangshuihe (XSH), which has an area of $43.74 \mathrm{~km}^{2}$ and an elevation range of 1960-2860 m a.s.l. The predominant soil type is hapli-ustic argosols, with sandy loam texture, and the thickness range of 50-300 $\mathrm{cm}$ according to site condition. The climate here is semi-humid continental monsoon, with a dry-cool winter and a warm-wet summer. According to the records from 1960-2010 at Jingyuan Weather 


\begin{tabular}{|l|l|l|l|l|}
\hline $\begin{array}{l}\text { Plot } \\
\text { No. }\end{array}$ & $\begin{array}{l}\text { Max } \mathbf{A}_{\text {S-tree }} \\
\mathbf{c m}^{2}\end{array}$ & $\begin{array}{l}\text { Min } \mathbf{A}_{\text {S-tree }} \\
\mathbf{c m}^{2}\end{array}$ & $\begin{array}{l}\text { Average } \mathbf{A}_{\text {S-tree }} \\
\mathbf{c m}^{2}\end{array}$ & $\begin{array}{l}\mathbf{A}_{\text {S-stand }} \\
\mathbf{m}^{2} \cdot \mathbf{h a}^{-1}\end{array}$ \\
\hline $\mathrm{P}_{1}$ & 387.05 & 38.78 & 166.77 & 15.50 \\
\hline $\mathrm{P}_{2}$ & 321.96 & 49.85 & 150.13 & 14.80 \\
\hline $\mathrm{P}_{3}$ & 287.57 & 23.40 & 143.09 & 16.30 \\
\hline
\end{tabular}

Table 3. Sapwood area of individual trees $\left(\mathrm{A}_{\mathrm{S} \text {-tree }}\right)$ and of stand $\left(\mathrm{A}_{\mathrm{S} \text {-stand }}\right)$ in 2014 at different plots.

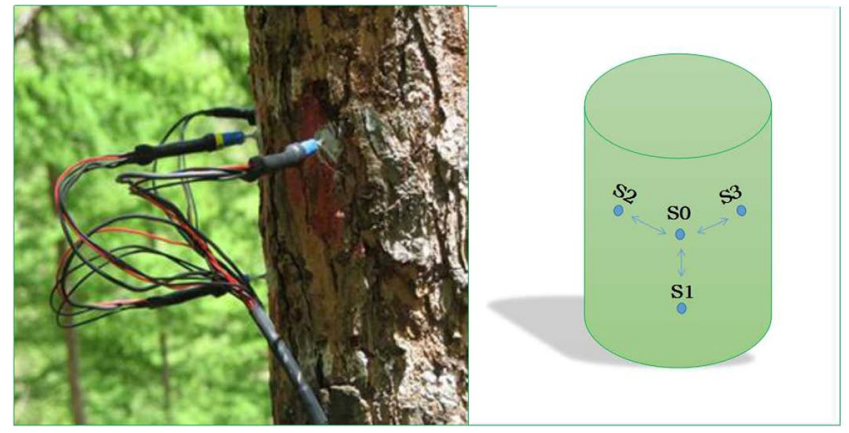

Figure 7. Radially inserted probes in hydro-active xylem of larch trunk to measure sap flow density.

Station about $7 \mathrm{~km}$ away from the study sites, the mean annual air temperature was $6.0^{\circ} \mathrm{C}$ and the mean annual precipitation $(\mathrm{P})$ was $610 \mathrm{~mm}$ with $87 \%$ concentrated in the period from June to September.

Since the 1980s, the forest coverage in XSH has been greatly increased by afforestation, with the main purposes to produce more timber and protect soil against erosion ${ }^{46}$. The plantation of Prince Rupprecht's larch, one dominant afforestation tree species in mountain areas of northwest and north China, is the dominant artificial forest, which accounts for $23.62 \%$ of the watershed area and is distributed mostly on shady, semi-shady and semi-sunny slopes.

Plot setup. In this study, one representative plot of larch plantation was set up in 2014 at the upper slope $\left(\mathrm{P}_{1}\right)$ and lower slope $\left(\mathrm{P}_{2}\right)$, respectively, on a southeast-facing hillslope with a gradient of $36.4^{\circ}$; meanwhile, another plot $\left(\mathrm{P}_{3}\right)$ was set up at the lower slope in 2013 on a south-facing hillslope with a gradient of $33.5^{\circ}$. The size of all plots was $30 \mathrm{~m}$ (width) $\times 30 \mathrm{~m}$ (slope length). An elevation difference of $117.6 \mathrm{~m}$ exists between $\mathrm{P}_{1}$ and $\mathrm{P}_{2}$. The plots $\mathrm{P}_{2}$ and $\mathrm{P}_{3}$ are at similar elevation, but separated by a horizontal distance of $210.6 \mathrm{~m}$ (Table 2). The micro-relief within plots is relatively uniform, without any obvious humps or concaves. The soil thickness is more than $100 \mathrm{~cm}$ for all plots. The mean bulk density of the $0-100 \mathrm{~cm}$ soil layer is around $1.1 \mathrm{~g} \cdot \mathrm{cm}^{-3}$.

All the trees in each plot had the same age of 33-years in 2014. The canopy density of the 3 plots was similar, varying within $0.74-0.80$. The understory shrubs were scattered due to the high canopy density. An herb layer was developed, with the coverage of about $40 \%$. The tree density (stocking) in the plots varied within 930-1139 trees $\cdot \mathrm{ha}^{-1}$, the mean diameter at breast height $(\mathrm{DBH})$ and mean height of trees varied within $18.48-20.49 \mathrm{~cm}$ and 14.85-19.07 m, respectively. The canopy LAI was measured at 11 random points dispersed within each plot using a LAI-2000 (Li-Cor Biosciences, Lincoln, NE, USA) once per week from May to September in 2014. The LAI range was similar among the three plots at 2.39-4.80 for $\mathrm{P}_{1}, 2.40-4.47$ for $\mathrm{P}_{2}$, and $2.47-4.70$ for $\mathrm{P}_{3}$, respectively.

Sap flow measurement and sapwood area. Sap flow was measured at 8 healthy sample trees within different DBH classes in each plot, using thermal dissipation probes (SF-L, Ecomatik, Munich, Germany). Each set of probes consisted of 4 sensors ( $\mathrm{S} 1$, a heated sensor, is powered by a constant current in $12 \mathrm{v}$ voltage. S0, S2, S3 are reference sensors) with a length of $20 \mathrm{~mm}$ and a diameter of $2 \mathrm{~mm}$ (Fig. 7). They were installed at breast height ( $1.3 \mathrm{~m}$ above ground) on the northern side of each tree trunk; then covered with aluminum foil to prevent direct solar radiation and physical damage, and to minimize temperature fluctuation in the sapwood area. Sap flow data were recorded on a data logger (DL2; Delta-T Devices, UK) with a multiplexer every $30 \mathrm{~s}$ and averaged in every $5 \mathrm{~min}$ interval. For trees with a sapwood thickness over $20 \mathrm{~mm}$, an additional system was installed at the sapwood depth of 20-40 $\mathrm{mm}$ from the cambium. The measurements were conducted in the entire growing season from May to September in 2014 (for $\mathrm{P}_{1}, \mathrm{P}_{2}, \mathrm{P}_{3}$ ) and 2013 (for $\mathrm{P}_{1}$ only).

The sapwood thickness $(\mathrm{mm})$ of more than 20 trees in each plot was measured by the Lintab5 rings analyzer (Rinntech, Heidelberg, Germany) and its software TSAP (time series analysis presentations) based on the cores extracted with a 5-mm increment borer at breast height, and assessed as the mean of two orthogonal measurements. The boundary between sapwood and heartwood was identified by wood color difference. The empirical power function between sapwood area $\left(\mathrm{A}_{\mathrm{S}}, \mathrm{cm}^{2}\right)$ and $\mathrm{DBH}(\mathrm{cm})$ of trees was established for each plot (Fig. 8).

The sapwood-DBH equations in Fig. 8 and the DBH of all trees in each plot were used to calculate the $\mathrm{A}_{s}$. The sapwood area per hectare $\left(\mathrm{m}^{2} \cdot \mathrm{ha}^{-1}\right)$ was calculated as the sum of sapwood area of all trees in each plot, which was 16.30 in $\mathrm{P}_{3}, 15.50$ in $\mathrm{P}_{1}$, and 14.80 in $\mathrm{P}_{2}$ in 2014 (Table 3). 

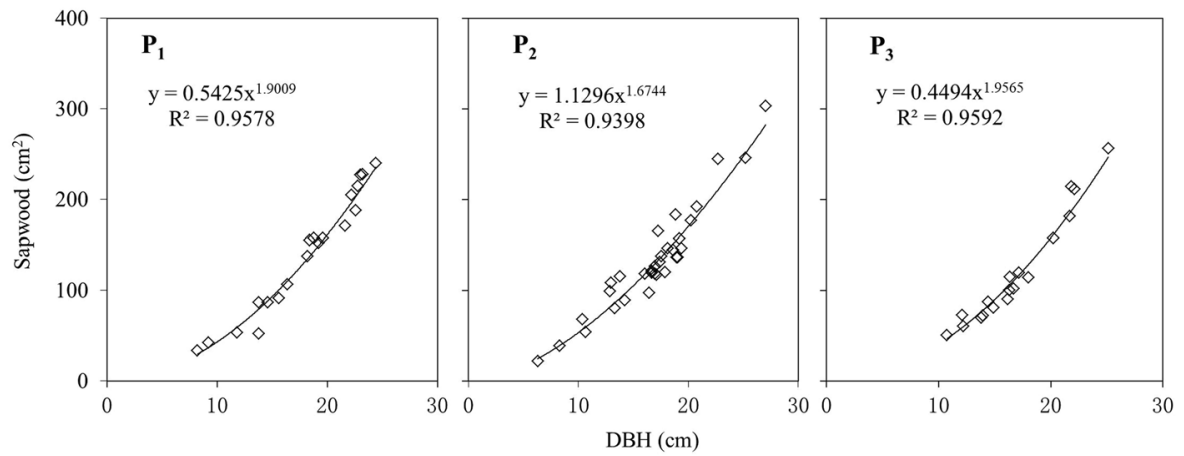

Figure 8. Variation of sapwood area with the DBH of individual trees in different plots.

Sap flow density and transpiration calculation. The sap flow density $\left(\mathrm{J}_{\mathrm{s}}\right)$ was calculated by Eqs $(5)$ and (6) as described by Xiong et al. ${ }^{20}$. The raw data were transferred to $J_{s}$ with the Baseliner Program (Version 3.0.7, $\mathrm{C}-\mathrm{H}_{2} \mathrm{O}$ Ecology Lab, Duke University, Durham, NC, USA).

$$
\begin{gathered}
\mathrm{J}_{\mathrm{s}}=0.714 \times\left(\frac{\mathrm{d}_{\mathrm{tmax}}}{\mathrm{d}_{\text {tact }}}-1\right)^{1.231} \\
\mathrm{~d}_{\text {tact }}=\mathrm{d}_{\mathrm{t} 0}-\frac{\left(\mathrm{d}_{\mathrm{t} 2}+\mathrm{d}_{\mathrm{t} 3}\right)}{2}
\end{gathered}
$$

where, $d_{\text {tact }}$ is the difference in instantaneous temperature $\left({ }^{\circ} \mathrm{C}\right)$ of the heated sensor and the reference sensors; $d_{\text {tmax }}$ is the value of $d_{\text {tact }}$ when sap flow is nil or close to zero; $d_{t 0}$ is the temperature difference between heated needle $\left(\mathrm{S}_{1}\right)$ and unheated needle $\left(\mathrm{S}_{0}\right)\left({ }^{\circ} \mathrm{C}\right), \mathrm{d}_{\mathrm{t} 2}$ and $\mathrm{d}_{\mathrm{t} 3}$ are the temperature difference between $\mathrm{S}_{1}$ and the probes of reference pair $\left(\mathrm{S}_{2}\right.$ and $\left.\mathrm{S}_{3}\right)$, respectively.

$\mathrm{J}_{\mathrm{s}}$ was corrected according to Clearwater et al. ${ }^{47}$ when the tree sapwood thickness was less than the probe length. For the trees with a sapwood thickness over $20 \mathrm{~mm}$, a radial profile of $\mathrm{J}_{\mathrm{s}}$ was calculated based on the method described by Xiong et al..$^{20}$.

The daily $\mathrm{T}\left(\mathrm{mm} \cdot \mathrm{day}^{-1}\right)$ was scaled up from sample trees to the stand level by Eq. (7).

$$
\mathrm{T}=J_{C} \times \frac{\sum \mathrm{A}_{\mathrm{s}}}{\mathrm{S} \times 1000} \times 60 \times 24
$$

where, $J_{c}\left(\mathrm{ml} \cdot \mathrm{cm}^{-2} \cdot \mathrm{min}^{-1}\right)$ is the stand daily mean sap flux density which was computed as the sapwood area weighted average of $J_{s}$ for each DBH class; $S\left(\mathrm{~m}^{2}\right)$ is the projected area of the plot; and $\sum \mathrm{A}_{\mathrm{s}}\left(\mathrm{cm}^{2}\right)$ is the cumulative sapwood area of all trees within the plot.

Weather and soil moisture measurement. An automatic weather station (Weatherhawk, USA) was placed in an open grassland, $110.9 \mathrm{~m}$ and $121.4 \mathrm{~m}$ away from the plot $\mathrm{P}_{2}$ and $\mathrm{P}_{3}$, respectively, to collect weather data including precipitation $(\mathrm{P}, \mathrm{mm})$, air temperature $\left(\mathrm{T},{ }^{\circ} \mathrm{C}\right)$, relative air humidity $(\mathrm{RH}, \%)$, solar radiation $(\mathrm{R}$, $\mathrm{w} \cdot \mathrm{m}^{-2}$ ) and wind speed $\left(\mathrm{U}, \mathrm{m} \cdot \mathrm{s}^{-1}\right)$. This weather station was $50 \mathrm{~m}$ beyond the forest edge, to minimize the canopy interference. The weather data were recorded every $5 \mathrm{~min}$. The daily potential evapotranspiration (PET, $\mathrm{mm})$ was calculated using the FAO Penman-Monteith calculation method ${ }^{48}$ for a reference grass surface, and directly obtained from the weather station.

Soil water potential $(\psi, \mathrm{MPa})$ was monitored with the equilibrium tensiometer (EQ. 15; Ecomatik, Munich, Germany) positioned at the soil depths of $5,15,30,50,70$ and $90 \mathrm{~cm}$ in the forest stand. Data were recorded every $5 \mathrm{~min}$ by a data logger (DL6; Delta-T Devices, UK) installed adjacent to the soil profile. The VSM $\left(\mathrm{m}^{3} \cdot \mathrm{m}^{-3}\right)$ was calculated from the raw data of $\psi$, by using their relation for each depth determined by the method of centrifugation with soil cylinder cores collected in the same study site ${ }^{49}$. The weighted average of VSM in the $0-100 \mathrm{~cm}$ soil layer was calculated based on the measured VSM in different soil depths using Eq. (8):

$$
\mathrm{VSM}_{0-100}=\left(\mathrm{VSM}_{5}+\mathrm{VSM}_{15}+2 \mathrm{VSM}_{30}+2 \mathrm{VSM}_{50}+2 \mathrm{VSM}_{70}+2 \mathrm{VSM}_{90}\right) / 10
$$

In addition, in order to apply the results to other regions with different soil hydrological properties, and also to ensure the results are comparable with other studies, VSM was converted into the REW using Eq. (9) as described by Granier ${ }^{50}$ :

$$
\mathrm{REW}=\left(\mathrm{VSM}-\mathrm{VSM}_{\mathrm{m}}\right) /\left(\mathrm{VSM}_{\mathrm{FC}}-\mathrm{VSM}_{\mathrm{m}}\right)
$$

where, VSM is the actual volumetric soil moisture in the root zone, $\mathrm{VSM}_{\mathrm{m}}$ is the value of VSM at the wilting point $(\psi=-1.5 \mathrm{MPa})$, and $\mathrm{VSM}_{\mathrm{FC}}$ is the VSM at the field capacity $(\psi=-0.01 \mathrm{MPa})$. 
An integrated model for daily T estimation. The model framework was adapted from the functions expressing the response of stomatal conductance to environmental variables ${ }^{51}$ and later used for $\mathrm{T}$ estimation in the studies of Oren \& Pataki ${ }^{22}$ and Phillips \& Oren ${ }^{44}$, using Eq. (10):

$$
\mathrm{T}=f_{1}(\mathrm{PET}) \cdot f_{2}(\mathrm{VSM}) \cdot f_{3}(\mathrm{LAI})
$$

where, $f_{1}, f_{2}, f_{3}$ are functions describing the variation of T with PET, VSM and LAI. Firstly, the concrete types of these functions were determined separately using the upper boundary line analysis of raw data observed in the field (Ram Oren's $\mathrm{H}_{2} \mathrm{O}$ Ecology Group in Duke University). A detailed description of this analysis can be found in Xiong et al. ${ }^{20}$. Then, the values of the parameters in Eq. (10) were fitted based on field data at $\mathrm{P}_{1}$ in 2014 , and the model was validated using the field data at $\mathrm{P}_{1}$ in 2013 and at $\mathrm{P}_{2}$ and $\mathrm{P}_{3}$ in 2014 . The fitting quality of the model was evaluated by a non-dimensional efficiency criterion of Nash and Sutcliffe ${ }^{52}$.

Statistical analysis. The SPSS software package (version 19.0 for Windows, SPSS Inc., USA) was used to determine the variance of T and VSM among different plots, and to realize the best-fit of the T model (Eq. (10)) which links the T variation to the PET, VSM and LAI.

\section{Data Availability}

The datasets generated during and/or analyzed during the current study are available from the corresponding author on reasonable request.

\section{References}

1. Lü, Y. H. et al. A policy-driven large scale ecological restoration: Quantifying ecosystem eservices changes in the Loess Plateau of China. Plos One 7, e31782 (2012).

2. Jian, S. Q., Zhao, C. Y., Fang, S. M. \& Yu, K. Effects of different vegetation restoration on soil water storage and water balance in the Chinese Loess Plateau. Agric. For. Meteorol. 206, 85-96 (2015).

3. Deng, L., Shangguan, Z. \& Sweeney, S. "Grain for Green" driven land use change and carbon sequestration on the Loess Plateau, China. Sci. Rep. 4, 7039 (2014).

4. Xie, X. H. et al. Detection and attribution of changes in hydrological cycle over the Three-North region of China: Climate change versus afforestation effect. Agric. For. Meteorol. 203, 74-87 (2015).

5. Yan, W., Deng, L., Zhong, Y. \& Shangguan, Z. The characters of dry soil layer on the Loess Plateau in China and their influencing factors. Plos One 10, e0134902 (2015).

6. Ren, Z. P. et al. Comparing watershed afforestation and natural revegetation impacts on soil moisture in the semiarid Loess Plateau of China. Sci. Rep. 8, 2972 (2018).

7. Shao, M. A., Jia, X. X., Wang, Y. Q. \& Zhu, Y. J. A review of studies on dried soil layers in the Loess Plateau. Adv. Earth Sci. 31, 14-22 (2016).

8. Sun, G. et al. Potential water yield reduction due to forestation across China. J. Hydrol. 328, 548-558 (2006).

9. Wang, Y. H. et al. Annual runoff and evapotranspiration of forestlands and non-forestlands in selected basins of the Loess Plateau of China. Ecohydrol. 4, 277-287 (2011).

10. Wang, Y. H. et al. Changing forestry policy by integrating water aspects into forest/vegetation restoration in dryland areas in China. Bull. Chin. Acad. Sci. 26, 59-67 (2012).

11. Parkhurst, D. F. \& Gates, D. M. Transpiration resistance and energy budget of Populus Sargentii leaves. Nature 210, 172-174 (1966).

12. Bearup, L. A., Maxwell, R. M., Clow, D. W. \& McCray, J. E. Hydrological effects of forest transpiration loss in bark beetle-impacted watersheds. Nature Clim. Change. 4, 481-486 (2014).

13. Bosch, D. D., Marshall, L. K. \& Teskey, R. Forest transpiration from sap flux density measurements in a Southeastern Coastal Plain riparian buffer system. Agric. For. Meteorol. 187, 72-82 (2014).

14. Granier, A. et al. Vapour flux density and transpiration rate comparisons in a stand of Maritime Pine (Pinus pinaster Ait.) in Les Landes forest. Agric. For. Meteorol. 51, 309-319 (1990).

15. Ungar, E. D. et al. Transpiration and annual water balance of Aleppo pine in a semiarid region: Implications for forest management. For. Ecol. Manage. 298, 39-51 (2013).

16. Lagergren, F. \& Lindroth, A. Transpiration response to soil moisture in pine and spruce trees in Sweden. Agric. For. Meteorol. 112, 67-85 (2002).

17. Sinclair, T. R., Holbrook, N. M. \& Zwieniecki, M. A. Daily transpiration rates of woody species on drying soil. Tree physiol. 25, 1469-1472 (2005).

18. Bucci, S. J. et al. Controls on stand transpiration and soil water utilization along a tree density gradient in a Neotropical savanna. Agric. For. Meteorol. 148, 839-849 (2008).

19. Moore, G. W., Bond, B. J. \& Jones, J. A. A comparison of annual transpiration and productivity in monoculture and mixed-species Douglas-fir and red alder stands. For. Ecol.Manage. 262, 2263-2270 (2011).

20. Xiong, W. et al. Heterogeneity of competition at decameter scale: patches of high canopy leaf area in a shade-intolerant larch stand transpire less yet are more sensitive to drought. Tree Physiol. 35, 470-484 (2015).

21. Sadras, V. O. \& Milroy, S. P. Soil-water thresholds for the responses of leaf expansion and gas exchange: a review. Field Crop. Res. 47, 253-266 (1996).

22. Oren, R. \& Pataki, D. E. Transpiration in response to variation in microclimate and soil moisture in southeastern deciduous forests. Oecologia. 127, 549-559 (2001).

23. Bernier, P. Y., Bréda, N., Granier, A., Raulier, F. \& Mathieu, F. Validation of a canopy gas exchange model and derivation of a soil water modifier for transpiration for sugar maple (Acer saccharum Marsh) using sap flow density measurements. For. Ecol. Manage. 163, 185-196 (2002).

24. Bindi, M. et al. Influence of water deficit stress on leaf area development and transpiration of Sangiovese grapevines grown in pots. Am. J. Enol. Viticul. 56, 68-72 (2005).

25. Wu, Y. Z., Huang, M. B. \& Warrington, D. N. Black locust transpiration responses to soil water availability as affected by meteorological factors and soil texture. Pedosphere. 25, 57-71 (2015).

26. Köstner, B., Biron, P., Siegwolf, R. \& Granier, A. Estimates of vapour flux and canopy conductance of Scots pine at the tree level utilizing different xylem sapflow methods. Theor. Appl. Climatol. 53, 105-113 (1996).

27. Clausnitzer, F., Köstner, B., Schwärzel, K. \& Bernhofer, C. Relationships between canopy transpiration, atmospheric conditions and soil water availability-Analyses of long-term sap-flow measurements in an old Norway spruce forest at the Ore Mountains/ Germany. Agric. For. Meteorol. 151, 1023-1034 (2011).

28. Komatsu, H. et al. A model relating transpiration for Japanese cedar and cypress plantations with stand structure. For. Ecol. Manage. 334, 301-312 (2014). 
29. Zhao, P., Yao, X.Q., Ma, L., Cai, X.A. \& Zeng, X.P. Sap flow-scaled stand transpiration and canopy stomatal conductance in an Acacia Mangium forest. J. plant ecol. 30, 655-665 (2006).

30. She, D. L., Xia, Y. Q., Shao, M. A., Peng, S. Z. \& Yu, S. G. Transpiration and canopy conductance of Caragana korshinskii trees in response to soil moisture in sand land of China. Agroforest. Syst. 87, 667-678 (2013).

31. Sun, L., Xiong, W., Guan, W., Wang, Y. H. \& Xu, L. H. Use of storage water in Larix principis-ruprechtii and its response to soil water content and potential evapotranspiration: a modeling analysis. J. plant ecol. 35, 411-421 (2011).

32. Huang, Y. Q. et al. Seasonal changes in Cyclobalanopsis glauca transpiration and canopy stomatal conductance and their dependence on subterranean water and climatic factors in rocky karst terrain. J. Hydrol. 402, 135-143 (2011).

33. Li, Z. H. et al. A model coupling the effects of soil moisture and potential evaporation on the tree transpiration of a semi-arid larch plantation. Ecohydrol. 10, https://doi.org/10.1002/eco.1764 (2017).

34. Linderson, M. L., Iritz, Z. \& Lindroth, A. The effect of water availability on stand-level productivity, transpiration, water use efficiency and radiation use efficiency of field-grown willow clones. Biomass Bioenrgy. 31, 460-468 (2007).

35. Schmidt, U., Hanspeter, T. \& Kaupenjohann, M. Using a boundary line approach to analyze $\mathrm{N}_{2} \mathrm{O}$ flux data from agricultural soils. Nutr. Cycl. Agroecosys. 57, 119-129 (2000).

36. Lundblad, M. \& Lindroth, A. Stand transpiration and sap flow density in relation to weather, soil moisture and stand characteristics. Basic Appl. Ecol. 3, 229-243 (2002).

37. Liu, C. F. et al. Quantifying evapotranspiration and biophysical regulations of a poplar plantation assesses by eddy covariance and sap-flow methods. J. plant ecol. 33, 706-718 (2009).

38. Forrester, D. I., Collopy, J. J., Beadle, C. L., Warren, C. R. \& Baker, T. Effect of thinning, pruning and nitrogen fertiliser application on transpiration, photosynthesis and water-use efficiency in a young Eucalyptus nitens plantation. For. Ecol. Manage. 266, 286-300 (2012).

39. Granier, A. \& Bréda, N. Modeling canopy conductance and stand transpiration of an oak forest from sap flow measurements. Ann. For. Sci. 53, 537-546 (1996).

40. Denmead, O. T. \& Shaw, R. H. Availability of soil water to plants as affected by soil moisture content and meteorological conditions. Agronomy J. 54, 385-390 (1962).

41. Wilson, K. B., Hanson, P. J., Mulholland, P. J., Baldocchi, D. D. \& Wullschleger, S. D. A comparison of methods for determining forest evapotranspiration and its components: sap-flow, soil water budget, eddy covariance and catchment water balance. Agric. For. Meteorol. 106, 153-168 (2001).

42. Wullschleger, S. D., Wilson, K. B. \& Hanson, P. J. Environmental control of whole-plant transpiration, canopy conductance and estimates of the decoupling coefficient for large red maple trees. Agric. For. Meteorol. 104, 157-168 (2002).

43. Sinclair, T. R., Wherley, B. G., Dukes, M. D. \& Cathey, S. E. Penman's sink-strength model as an improved approach to estimating plant canopy transpiration. Agric. For. Meteorol. 197, 136-141 (2014).

44. Phillips, N. \& Oren, R. Intra-, and inter-annual variation in transpiration of a pine forest. Ecol. Appl. 11, 385-396 (2001).

45. Zapater, M., Bréda, N., Bonal, D., Pardonnet, S. \& Granier, A. Differential response to soil drought among co-occurring broadleaved tree species growing in a 15- to 25-year-old mixed stand. Ann. For. Sci. 70, 31-39 (2013).

46. Wang, Y. H. et al. A water yield-oriented practical approach for multifunctional forest management and its application in dryland regions of China. J. Am. Water Resour. As. 51, 689-703 (2015).

47. Clearwater, M. J., Meinzer, F. C., Andrade, J. L., Goldstein, G. \& Holbrook, N. M. Potential errors in measurement of nonuniform sap flow using heat dissipation probes. Tree Physiol. 19, 681-687 (1999).

48. Allen, R. G., Pereira, L. S., Raes, D. \& Smith, M. Crop evapotranspiration - Guidelines for computing crop water requirements - FAO Irrigation and drainage paper. 56, 1-15 (1998).

49. Shi, Z. J. The eco-hydrological effects of hillslope forest/vegetation in the small watershed of Xiangshuihe, Liupanshan Mountains. Beijing: PhD thesis of Chinese Academy of Forestry (2006).

50. Granier, A. Evaluation of transpiration in a Douglas-fir stand by means of sap flow measurements. Tree Physiol. 3, 309-319 (1987).

51. Jarvis, P. G. The interpretation of the variations in leaf water potential and stomatal conductance found in canopies in the field. Philos. Trans. R. Soc. London. Ser. B. 273, 593-610 (1976).

52. McCuen, R. H., Knight, Z. \& Cutter, A. G. Evaluation of the Nash-Sutcliffe efficiency index. J. Hydrol. Eng. 11, 597-602 (2006).

\section{Acknowledgements}

This work was funded by the National Key R \& D Program of China (2017YFC0504602, 2016YFC0501603) and the National Natural Science Foundation of China (41671025), and the long-term forest ecological station of Liupan Mountains of the National Forestry and Grassland Administration of China.

\section{Author Contributions}

Yanhui Wang designed research, applied funding, supervised project running and data analyses, and wrote/ revised manuscript. Yunni Wang and Gongxia Cao co-designed research, collected and analyzed data, and wrote/ revised manuscript. Ashley A. Webb supervised analyses, revised manuscript, and improved English. Pengtao Yu co-performed funding application, project management, research design, and manuscript revision. Xiaojiang Wang contributed to data analysis and manuscript writing.

\section{Additional Information}

Competing Interests: The authors declare no competing interests.

Publisher's note: Springer Nature remains neutral with regard to jurisdictional claims in published maps and institutional affiliations.

(c) (i) Open Access This article is licensed under a Creative Commons Attribution 4.0 International

License, which permits use, sharing, adaptation, distribution and reproduction in any medium or format, as long as you give appropriate credit to the original author(s) and the source, provide a link to the Creative Commons license, and indicate if changes were made. The images or other third party material in this article are included in the article's Creative Commons license, unless indicated otherwise in a credit line to the material. If material is not included in the article's Creative Commons license and your intended use is not permitted by statutory regulation or exceeds the permitted use, you will need to obtain permission directly from the copyright holder. To view a copy of this license, visit http://creativecommons.org/licenses/by/4.0/.

(C) The Author(s) 2019 